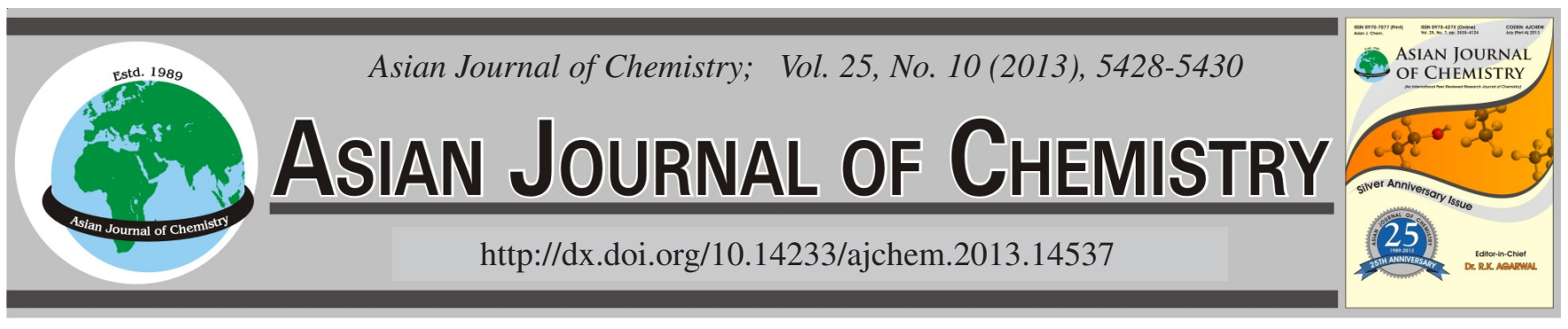

\title{
Synthesis and Structural Characterization of a Novel Carboxy-Functionalized Diiron Dithiolate Complex
}

\author{
Pei-Hua Zhao*, Ya-Qing Liu and Xin-ANG Li
}

Research Center for Engineering Technology of Polymeric Composites of Shanxi Province, College of Materials Science and Engineering, North University of China, Taiyuan 030051, P.R. China

*Corresponding author: Tel./Fax: + 86351 3559669; E-mail: zph2004@yahoo.com.cn

(Received: 7 September 2012;

Accepted: 10 April 2013)

AJC-13222

\begin{abstract}
A novel carboxy-functionalized diiron dithiolate complex, $\left[\left(\mu-\mathrm{SCH}_{2}\right)_{2} \mathrm{NCH}_{2} \mathrm{CH}_{2} \mathrm{CO}_{2} \mathrm{CH}_{2} \mathrm{CH}_{2} \mathrm{Cl}\right]\left[\mathrm{Fe}_{2}(\mathrm{CO})_{6}\right](\mathbf{I})$ as active site model of [FeFe]-hydrogenase, has been successfully synthesized by condensation reaction of $\left[\left(\mu-\mathrm{SCH}_{2}\right)_{2} \mathrm{NCH}_{2} \mathrm{CH}_{2} \mathrm{CO}_{2} \mathrm{H}\right]\left[\mathrm{Fe}_{2}(\mathrm{CO})_{6}\right](\mathbf{A})$ with $\mathrm{HOCH}_{2} \mathrm{CH}_{2} \mathrm{Cl}$ in the presence of 4-dimethylaminopyridine and dicyclohexylcarbodiimide. Its structure was characterized by combustion analysis, ESI-MS, IR and ${ }^{1} \mathrm{H}\left({ }^{13} \mathrm{C}\right)$ NMR spectroscopic techniques.

Key Words: Carboxy-functionalized, Diiron dithiolate, Synthesis, Structural characterization.
\end{abstract}

\section{INTRODUCTION}

Over the last two decades, the diiron dithiolate complexes have received considerable attention, not only because of their interesting chemistry ${ }^{1}$ but also due to their close relevance to the active site of [FeFe]-hydrogenase that can efficiently catalyze the production and the uptake of dihydrogen ${ }^{2}$. The crystallographic and theoretical investigations ${ }^{3,4}$ have demonstrated that $[\mathrm{FeFe}]$-hydrogenase features a butterfly $2 \mathrm{Fe}_{2} \mathrm{~S}$ subunit as its active site (Scheme-I). In the active site, the iron centers are coordinated by carbon monoxide, cyanide ligands and by a bridging dithiolate ligand between the two iron centers, one of which is coordinated by a cysteinyl-S-linked cubic $4 \mathrm{Fe}_{4} \mathrm{~S}$ cluster (Scheme-I). Further studies have revealed that the bridging dithiolate in the $\mathrm{H}$-cluster could be supposed to be propanedithiolate $\left(\mathrm{SCH}_{2} \mathrm{CH}_{2} \mathrm{CH}_{2} \mathrm{~S} \text {, namely, pdt }\right)^{5}$, azadithiolate $\left(\mathrm{SCH}_{2} \mathrm{NCH}_{2} \mathrm{~S} \text {, namely, adt }\right)^{6}$ and oxadithiolate $\left(\mathrm{SCH}_{2} \mathrm{OCH}_{2} \mathrm{~S} \text {, namely, odt }\right)^{7}$ (Scheme-I).

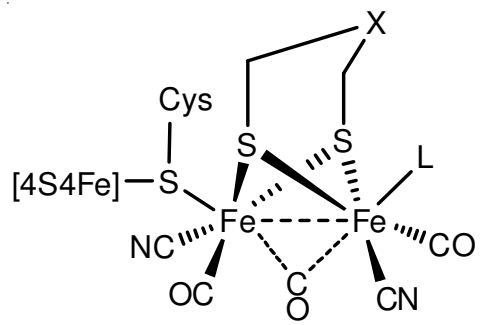

$\left(\mathrm{L}=\mathrm{H}_{2} \mathrm{O}, \mathrm{CO}\right.$, or vacant; $\mathrm{X}=\mathrm{C}, \mathrm{N}$, or $\left.\mathrm{O}\right)$

Scheme-I: Proposed active site of [FeFe]-hydrogenase
The above-mentioned information provoked chemists to design and prepare a range of diiron dithiolate complexes $^{8}$ in order to better mimic the active site of $[\mathrm{FeFe}]-$ hydrogenase. Akermark and co-workers ${ }^{9}$ prepared the carboxy-containing adt-diiron dithiolate complexes $[(\mu$ $\left.\left.\mathrm{SCH}_{2}\right)_{2} \mathrm{NCH}_{2} \mathrm{CH}_{2} \mathrm{CO}_{2} \mathrm{H}\right]\left[\mathrm{Fe}_{2}(\mathrm{CO})_{6}\right]$ and $\left[\left(\mu-\mathrm{SCH}_{2}\right)_{2} \mathrm{NCH}_{2} \mathrm{CH}_{2}\right.$ $\left.\mathrm{CO}_{2} \mathrm{H}\right]\left[\mathrm{Fe}_{2}(\mathrm{CO})_{4}\left(\mathrm{PMe}_{3}\right)_{2}\right]$, which are regarded as active site models of [FeFe]-hydrogenase.

In order to extend this study on such model complex, we herein report the synthesis and structural characterization of a new carboxy-functionalized diiron dithiolate complex [ $\mu$ $\left.\left.\mathrm{SCH}_{2}\right)_{2} \mathrm{NCH}_{2} \mathrm{CH}_{2} \mathrm{CO}_{2} \mathrm{CH}_{2} \mathrm{CH}_{2} \mathrm{Cl}\right]\left[\mathrm{Fe}_{2}(\mathrm{CO})_{6}\right]$ (I) related to the active site of $[\mathrm{FeFe}]$-hydrogenase.

\section{EXPERIMENTAL}

Reaction and operation was carried out under a dry, oxygenfree nitrogen atmosphere with standard Schlenk and vacuumline techniques. Dichloromethane was distilled with $\mathrm{CaH}_{2}$ under $\mathrm{N}_{2}$. Dicyclohexylcarbodiimide (DCC), 4-dimethylamino pyridine (DMAP), $\mathrm{HOCH}_{2} \mathrm{CH}_{2} \mathrm{Cl}$ and other materials were commercially available and used as received. [ $\mu$ $\left.\left.\mathrm{SCH}_{2}\right)_{2} \mathrm{NCH}_{2} \mathrm{CH}_{2} \mathrm{CO}_{2} \mathrm{H}\right]\left[\mathrm{Fe}_{2}(\mathrm{CO})_{6}\right]$ (A) was prepared according to the literature procedures ${ }^{9}$. Preparative TLC was carried out on glass plates $(25 \mathrm{~cm} \times 20 \mathrm{~cm} \times 0.25 \mathrm{~cm})$ coated with silica gel $\mathrm{H}$ (10-40 mm). IR spectra were recorded on a Nicolet 670 FTIR spectrometer. ${ }^{1} \mathrm{H}\left({ }^{13} \mathrm{C}\right)$ NMR spectra were obtained on a Bruker Avance $400 \mathrm{MHz}$ spectrometer. Mass spectrometric studies (ESI-MS) were carried out on Finnigan 
LCQ-Advantage spectrometer. Elemental analyses were performed on a Perkin-Elmer 240C analyzer.

Synthetic procedure: The $\mathrm{CH}_{2} \mathrm{Cl}_{2}(20 \mathrm{~mL})$ solution of $\left[\left(\mu-\mathrm{SCH}_{2}\right)_{2} \mathrm{NCH}_{2} \mathrm{CH}_{2} \mathrm{CO}_{2} \mathrm{H}\right]\left[\mathrm{Fe}_{2}(\mathrm{CO})_{6}\right](\mathbf{A})(0.458 \mathrm{~g}, 1.0 \mathrm{mmol})$, DCC $(0.206 \mathrm{~g}, 1.0 \mathrm{mmol})$ and 4-dimethylamino pyridine $(0.013 \mathrm{~g}, 0.1 \mathrm{mmol})$ was stirred at room temperature for $5 \mathrm{~min}$. To this mixture $\mathrm{HOCH}_{2} \mathrm{CH}_{2} \mathrm{Cl}(0.1 \mathrm{~mL}, 1.5 \mathrm{mmol})$ was added and the new mixture was stirred at room temperature for $12 \mathrm{~h}$. The solvent was removed under reduced pressure and the residue was subjected to preparative TLC separation using $\mathrm{CH}_{2} \mathrm{Cl}_{2}$ /petroleum ether (v/v = 1:2) as eluent. From the main red band, the title complex (I) $(0.209 \mathrm{~g}, 40 \%)$ was obtained as a red oil. Anal. calcd (\%) for $\mathrm{C}_{13} \mathrm{H}_{12} \mathrm{NO}_{8} \mathrm{~S}_{2} \mathrm{ClFe}_{2}$ : C 29.94, H 2.32, N 2.69; found (\%): C 29.68, H 2.52, N 2.71. ESI-MS $\left(\mathrm{CH}_{2} \mathrm{Cl}_{2}\right.$, positive mode $): \mathrm{m} / \mathrm{z}=521.8[\mathrm{M}+\mathrm{H}]^{+}$(calcd. $(\%)$ for 521.8); IR ( $\mathrm{KBr}$ disk, $\mathrm{cm}^{-1}$ ): $\mathrm{v}_{\mathrm{C} \equiv \mathrm{O}} 2073$ (vs), 2030 (vs), 1992 (vs); $\mathrm{v}_{\mathrm{C}(\mathrm{O}) \mathrm{O}} 1735$ (s). ${ }^{1} \mathrm{H}$ NMR (400 MHz, $\left.\mathrm{CDCl}_{3}, \mathrm{TMS}\right)$ : $\delta=4.30\left(\mathrm{~s}, 2 \mathrm{H}, \mathrm{OCH}_{2}\right), 3.66\left(\mathrm{~s}, 2 \mathrm{H}, \mathrm{CH}_{2} \mathrm{Cl}\right), 3.58(\mathrm{~s}, 4 \mathrm{H}$, $\left.2 \mathrm{NCH}_{2} \mathrm{~S}\right), 3.04\left(\mathrm{~s}, 2 \mathrm{H}, \mathrm{NCH}_{2}\right), 2.36\left(\mathrm{~s}, 2 \mathrm{H}, \mathrm{CH}_{2} \mathrm{C}(\mathrm{O})\right)$ ppm. ${ }^{13} \mathrm{C}\left\{{ }^{1} \mathrm{H}\right\} \mathrm{NMR}\left(100.6 \mathrm{MHz}, \mathrm{CDCl}_{3}, \mathrm{TMS}\right): \delta=207.7$ (FeCO), $171.2(\mathrm{C}(\mathrm{O}) \mathrm{O}), 64.3\left(\mathrm{OCH}_{2}\right), 52.7\left(\mathrm{NCH}_{2} \mathrm{~S}\right), 52.2\left(\mathrm{NCH}_{2}\right)$, $41.5\left(\mathrm{CH}_{2} \mathrm{Cl}\right), 33.0\left(\mathrm{CH}_{2} \mathrm{C}(\mathrm{O})\right)$ ppm.

\section{RESULTS AND DISCUSSION}

As shown in Scheme-II, the treatment of the starting material $\left[\left(\mu-\mathrm{SCH}_{2}\right)_{2} \mathrm{NCH}_{2} \mathrm{CH}_{2} \mathrm{CO}_{2} \mathrm{H}\right]\left[\mathrm{Fe}_{2}(\mathrm{CO})_{6}\right](\mathbf{A})$ with 0.1 equiv. 4-dimethylaminopyridine in the presence of dicyclohexylcarbodiimide as a dehydrating agent in $\mathrm{CH}_{2} \mathrm{CH}_{2}$ followed by addition of 1.5 equiv. $\mathrm{HOCH}_{2} \mathrm{CH}_{2} \mathrm{Cl}$, afforded the title complex (I) in the yield of $40 \%$.

The title complex (I) was stable in air and soluble in most organic solvents such as dichloromethane, acetone and ethyl acetate, etc. Its molecular structure was fully characterized by satisfactory ESI-MS, IR, ${ }^{1} \mathrm{H}$ NMR,${ }^{13} \mathrm{C}$ NMR spectroscopy and elemental analysis.

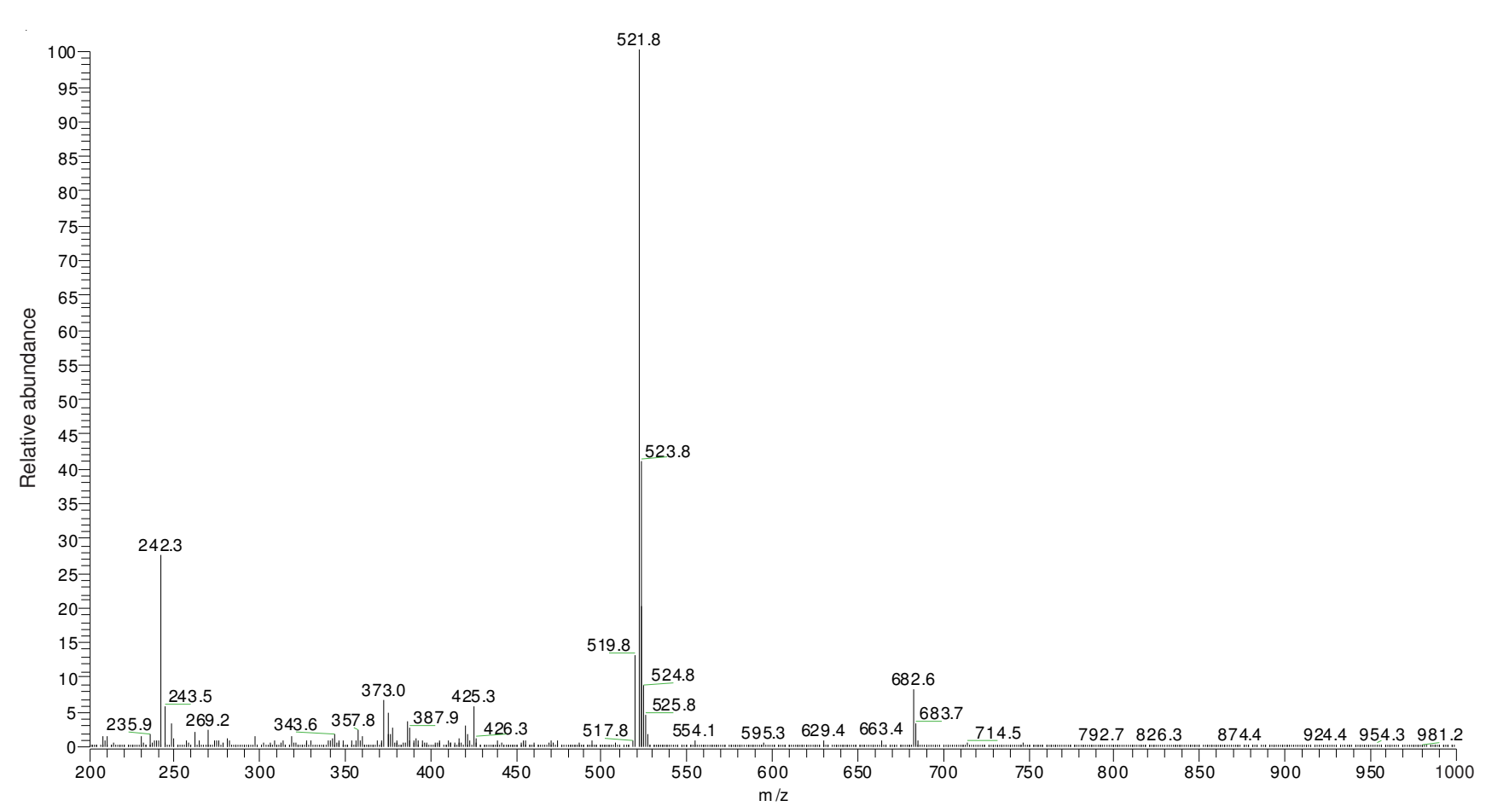

Fig. 1. ESI-MS spectrum of the title complex (I) (in $\mathrm{CH}_{2} \mathrm{Cl}_{2}$ )

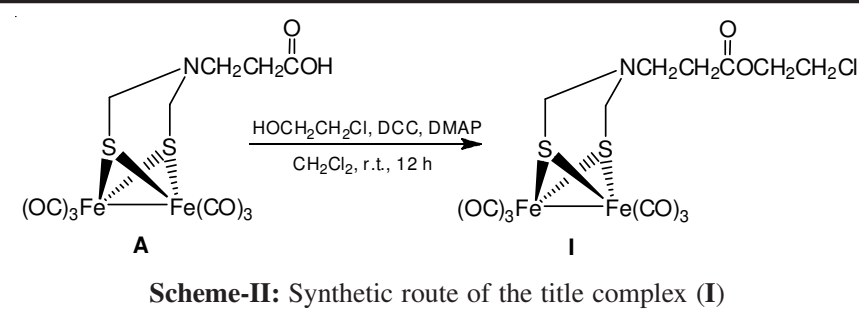

Mass spectrum: As displayed in Fig. 1, the positive mode ESI-MS spectrum of (I) gave the quasimolecular ion peak [M $+\mathrm{H}^{+}$at $\mathrm{m} / \mathrm{z} 521.8$, which is in good agreement with its molecular formula of $\mathrm{C}_{13} \mathrm{H}_{12} \mathrm{ClFe}_{2} \mathrm{NO}_{8} \mathrm{~S}_{2}$.

Infrared spectrum: The IR spectrum of (I) in $\mathrm{KBr}$ displayed three strong absorption bands in the range of 2076$1992 \mathrm{~cm}^{-1}$ for the terminal carbonyls coordinated to iron atom. Especially, its IR data is very similar to that of the parent complex $\left[\left(\mu-\mathrm{SCH}_{2}\right)_{2} \mathrm{NCH}_{2} \mathrm{CH}_{2} \mathrm{CO}_{2} \mathrm{H}\right]\left[\mathrm{Fe}_{2}(\mathrm{CO})_{6}\right](\mathbf{A})^{9}$ with exception of the disappearance of the $1709 \mathrm{~cm}^{-1}$ for (A) and the appearance of one new band $1735 \mathrm{~cm}^{-1}$ for (I), indicating that the carboxyl group was converted to the ester carbonyl functionality (Table-1).

\begin{tabular}{|c|c|c|}
\hline \multicolumn{3}{|c|}{$\begin{array}{c}\text { TABLE-1 } \\
\text { IR DATA OF THE TITLE COMPLEX (I) (IN KBr) AND } \\
\text { THE PARENT COMPLEX (A) FOR COMPARISON }\end{array}$} \\
\hline Complex & $v(\mathrm{CO}) \mathrm{Fe}\left(\mathrm{cm}^{-1}\right)$ & $\mathrm{v}(\mathrm{C}=\mathrm{O})\left(\mathrm{cm}^{-1}\right)$ \\
\hline I & 2073 (vs), 2030 (vs), 1992 (vs) & $1735(\mathrm{~m})$ \\
\hline $\mathbf{A}^{\mathrm{a}}$ & 2073 (m), 2029 (s), 1991 (s) & $1709(\mathrm{~m})$ \\
\hline
\end{tabular}

${ }^{1} \mathbf{H}\left({ }^{13} \mathbf{C}\right)$ NMR spectrum: The ${ }^{1} \mathrm{H}$ NMR spectrum of (I) exhibited two singlets at $\delta 4.30$ and $3.66 \mathrm{ppm}$ assigned to the methylene protons, which was consistent with two carbon signals at $\delta 64.3$ and $41.5 \mathrm{ppm}$ for the respective oxygen- and chloride-bearing carbon atoms in the ${ }^{13} \mathrm{C}$ NMR spectrum,

Fig. 1. ESI-MS spectrum of the title complex (I) (in $\left.\mathrm{CH}_{2} \mathrm{Cl}_{2}\right)$ 
showing the appearance of the $\mathrm{OCH}_{2} \mathrm{CH}_{2} \mathrm{Cl}$ group. Meanwhile, because of the quick conversion of the iron dithiacyclohexane ring, its ${ }^{1} \mathrm{H}$ NMR spectrum displayed only one singlet at $\delta$ $3.58 \mathrm{ppm}$ for four equivalently methylene protons, which was in accordance with one carbon signal at $\delta 52.7 \mathrm{ppm}$ ascribed to nitrogen-containing carbon atoms in the ${ }^{13} \mathrm{C}$ NMR, demonstrating the existing of the azadithiolate unit (namely, the $-\mathrm{SCH}_{2} \mathrm{NCH}_{2} \mathrm{~S}$ - group). In addition, the ${ }^{13} \mathrm{C} \mathrm{NMR}$ spectrum of (I) showed one downfield carbon signal at $\delta 207.7 \mathrm{ppm}$ for the coordinated carbonyl carbon atoms linked to the iron atoms. Particularly, there was one typical ester carbonyl carbon signal at $\delta 171.2 \mathrm{~cm}^{-1}$ in ${ }^{13} \mathrm{C}$ NMR spectrum, further confirming that the carboxyl group of the parent complex (A) was transformed into the ester carbonyl group of the title complex (I) via the condensation reaction.

\section{Conclusion}

To better mimic the active site of [FeFe]-hydrogenase, we successfully synthesized a novel carboxy-functionalized diiron dithiolate complex $\left[\left(\mu-\mathrm{SCH}_{2}\right)_{2} \mathrm{NCH}_{2} \mathrm{CH}_{2} \mathrm{CO}_{2} \mathrm{CH}_{2} \mathrm{CH}_{2} \mathrm{Cl}\right]$ $\left[\mathrm{Fe}_{2}(\mathrm{CO})_{6}\right]$ (I) from (A) and $\mathrm{HOCH}_{2} \mathrm{CH}_{2} \mathrm{Cl}$. The new model complex (I) was structurally characterized by various spectroscopic techniques including ESI-MS, FT-IR, ${ }^{1} \mathrm{H}$ NMR as well as ${ }^{13} \mathrm{C}$ NMR.

\section{ACKNOWLEDGEMENTS}

This work was financially supported by the National Natural Science Foundation of China (No. 51102216) and Shanxi Province Science Foundation for Youths (No. 2012021007-4).

\section{REFERENCES}

1. (a) H. Ogino, S. Inomata and H. Tobita, Chem. Rev., 98, 2093 (1998); (b) L.C. Song, Trends Organomet. Chem., 3, 1 (1999); (c) L.C. Song, Acc. Chem. Res., 38, 21 (2005); (d) L.C. Song, P.H. Zhao, Z.Q. Du, M.Y. Tang and Q.M. Hu, Organometallics, 29, 5751 (2010).

2. (a) M. Stephenson and L.H. Stickland, Biochem. J., 25, 205 (1931); (b) R. Cammack, Nature, 397, 214 (1999); (c) M.Y. Darensbourg, E.J. Lyon and J.J. Smee, Coord. Chem. Rev., 206-207, 533 (2000); (d) J.F. Capon, F. Gloaguen, P. Schollhammer and J. Talarmin, Coord. Chem. Rev., 249, 1664 (2005); (e) J.C. Fontecilla-Camps, A. Volbeda, C. Cavazza and Y. Nicolet, Chem. Rev., 107, 4273 (2007).

3. J.W. Peters, W.N. Lanzilotta, B.J. Lemon and L.C. Seefeldt, Science, 282, 1853 (1998).

4. Y. Nicolet, C. Piras, P. Legrand, C.E. Hatchikian and J.C. FontecillaCamps, Structure, 7, 13 (1999).

5. A. Le Cloirec, S.P. Best, S.C. Davies, D.J. Evans, D.L. Hughes and C.J. Pickett, Chem. Commun., 2285 (1999).

6. H. Fan and M.B. Hall, J. Am. Chem. Soc., 123, 3828 (2001).

7. Y. Nicolet, B.J. Lemon, J.C. Fontecilla-Camps and J.W. Peters, Trends Biochem. Sci., 25, 138 (2000).

8. (a) C. Tard and C.J. Pickett, Chem. Rev., 109, 2245 (2009); (b) F. Gloaguen and T.B. Rauchfuss, Chem. Soc. Rev., 38, 100 (2009); (c) M.H. Harb, U.P. Apfel, T. Sakamoto, M. EI-khateeb and W. Weigand, Eur. J. Inorg. Chem., 986 (2011); (d) M.Y. Darensbourg and W. Weigand, Eur. J. Inorg. Chem., 994 (2011); (e) X.F. Liu and Y.B. Shao, J. Coord. Chem., 63, 4061 (2010); (f) X.F. Liu, X.W. Xiao and L.J. Shen, J. Coord. Chem., 64, 1023 (2011); (g) B.S. Yin, T.B. Li and M.S. Yang, J. Coord. Chem., 64, 2066 (2011).

9. W.M. Gao, J.L. Sun, T. Åkermark, M.R Li, L. Eriksson, L. Sun and B. Åkermark, Chem. Eur. J., 16, 2537 (2010). 